\title{
Exosome-associated host-pathogen interaction: a potential effect of biofilm formation
}

\author{
Dibyajit Lahiri ${ }^{1 \dagger}$, Moupriya Nag ${ }^{1 \dagger}$, Ankita Dey ${ }^{2}$, Tanmay Sarkar ${ }^{3,4}$, Smaranika Pattnaik ${ }^{5}$, Sougata Ghosh ${ }^{6}$, \\ Hisham Atan Edinur ${ }^{7}$, Siddhartha Pati ${ }^{8,9}$ (D, Zulhisyam Abdul Kari ${ }^{10^{*}}$ and Rina Rani Ray ${ }^{2^{*}+}$
}

\begin{abstract}
Exosomes being non-ionized micro-vesicles with a size range of 30-100 nm possess the ability to bring about intracellular communication and intercellular transport of various types of cellular components like miRNA, mRNA, DNA, and proteins. This is achieved through the targeted transmission of various inclusions to nearby or distant tissues. This is associated with the effective communication of information to bring about changes in physiological properties and functional attributes. The extracellular vesicles (EVs), produced by fungi, parasites, and bacteria, are responsible to bring about modulation/alteration of the immune responses exerted by the host body. The lipids, nucleic acids, proteins, and glycans of EVs derived from the pathogens act as the ligands of different families of pattern recognition receptors of the host body. The bacterial membrane vesicles (BMVs) are responsible for the transfer of small RNA species, along with other types of noncoding RNA thereby playing a key role in the regulation of the host immune system. Apart from immunomodulation, the BMVs are also responsible for bacterial colonization in the host tissue, biofilm formation, and survival therein showing antibiotic resistance, leading to pathogenesis and virulence. This mini-review would focus on the role of exosomes in the development of biofilm and consequent immunological responses within the host body along with an analysis of the mechanism associated with the development of resistance.
\end{abstract}

Keywords: Exosomes, Membrane vesicles, Immunogenic response, Biofilm, Resistance, Bioprospecting

\section{Introduction}

Exosomes being a type of extracellular vesicles (EVs) are membrane-bound structures released mostly by prokaryotic and eukaryotic cells that help in secreting various types of biomolecules in a protected and concentrated manner. These are highly heterogeneous population and have distinct capacities to induce a

\footnotetext{
*Correspondence: zulhisyam.a@umk.edu.my; raypumicro@gmail.com ${ }^{\dagger}$ Dibyajit Lahiri, Moupriya Nag and Rina Rani Ray have contributed equally to this work

${ }^{2}$ Department of Biotechnology, Maulana Abul Kalam Azad University of Technology, West Bengal, Haringhata, India

${ }^{10}$ Faculty of Agro Based Industry, Universiti Malaysia Kelantan, Jeli, Malaysia

Full list of author information is available at the end of the article
}

multifaceted biological response. The array of exosomes may be abstracted on the basis of their size, content (cargo), effect on recipient cells, and origin (Kalluri and LeBleu 2020). EVs are the group of membrane-bound, nanosized vesicles that are being released by the cells and are responsible for the transportation of RNA, DNA, and proteins as molecules responsible for intercellular communication system (Zaborowski et al. 2015).

The diameter of the vesicles ranges from 10 to $300 \mathrm{~nm}$ and comprises of proteins, phospholipids, lipopolysaccharides, DNA, RNA, and lipids (Bonnington and Kuehn 2014). The size range of biofilm EVs suggests that they are actually exosomes (Abels and Breakefield 2016). The biological functionality and their ubiquitous prevalence in bacteria, dimorphic fungi, and eukaryotes have 
warranted an extensive study of these exosomes and their contribution toward infectivity.

It was found that in the pathogenic bacteria, the toxin delivery is accomplished by EVs that results in the damage of host cell. The secretion of the virulence factor by the Gram-negative bacteria that help them to combat host immunity is a complex phenomenon as it remains covered by lipid bilayer (Henderson et al. 2004). Mycobacterial extracellular vesicles (MEVs) are also studied for decades that remain embedded within the extracellular matrix of Mycobacterium ulcerans biofilms (Marsollier et al. 2007). Although the transport pattern of secretory vesicles differs from each other, the direct secretion of protein to extracellular milieu or to the nearby cells is the specific characteristic for the pathogenic bacterial cells.

The present mini review will focus on the contribution of biofilm exosomes in maintenance of cell-to-cell communication and acquisition of immune resistance for host-pathogen interactions.

Exosomes' being a type of extracellular vesicles (EVs) are membrane-bound structures released mostly by prokaryotic and eukaryotic cells that help in secreting various types of biomolecules in a protected and concentrated manner. These are highly heterogeneous populations, comprised of proteins, phospholipids, lipopolysaccharides, DNA, RNA, and lipids (Bonnington and Kuehn 2014), thus distinct capacities to induce a multifaceted biological response. The arrays of exosomes are abstracted on the basis of their size, content (cargo), effect on recipient cells, and origin (Kalluri and LeBleu 2020).

The diameter of the vesicles ranges from 10 to $300 \mathrm{~nm}$ and density of $1.10-1.18 \mathrm{~g} / \mathrm{mL}$ (Samanta et al. 2018). The biological functionality and their ubiquitous prevalence in bacteria, dimorphic fungi, and eukaryotes have warranted an extensive study of these exosomes and their contribution toward infectivity.

It was found that in the pathogenic bacteria, the toxin delivery is accomplished by EVs that results in the damage of the host cell. The secretion of the virulence factor by the Gram-negative bacteria that help them to combat host immunity is a complex phenomenon as it remains covered by a lipid bilayer (Henderson et al. 2004). Mycobacterial extracellular vesicles (MEVs) are also studied for decades that remain embedded within the extracellular matrix of Mycobacterium ulcerans biofilms (Marsollier et al. 2007). Exosomes (Outer Membrane Vesicles) play important roles in interspecies communication, the delivery of proteins, toxins, and DNA or RNA, it is thought that there is a direct correlation with biofilm, like contribution of outer membrane proteins to biofilm (Sieke et al. 2020), although the understanding is still in opaque (Wang et al. 2015). This is to add here that OMVs have almost exclusively been studied using planktonic cultures, little is known about their biogenesis and function in biofilms (Cooke et al. 2019) produced by pathogenic bacteria (Table 1).

The present pursuit in mini review form will focus on the contribution of biofilm exosomes in the formation of biofilm, maintenance of cell-to-cell communication and acquisition of immune resistance for host-pathogen interactions.

\section{Membrane vesicles (MV) and biofilm formation}

By definition, exosomes of both Gram-positive and Gram-negative bacteria are called Membrane vesicles (MV), while the outer membrane vesicle, OMV (Cooke et al. 2019) is assigned to MV of Gram-negatives as it had borrowed the outer membrane (lipopolysaccharide [LPS], phospholipids, and integral membrane proteins) of Gram-negative bacteria (Caruana and Walper 2020).

OMVs that produced by the Gram-negative bacterial cells are spherical membrane-bound structure and endocytic in nature, synthesis of which is found to be necessary for the existence of the microbial consortia existing in the biofilm. Prior to resist the action of prescribed antibiotics, drug-resistant bacteria display OMVs, (The proteoliposomal nanoparticles). The exopolysachharides (EPS) is fundamental unit of biofilm, is released through the OMVs for biofilm organization. Further, it was observed that OMVs can give adhesive anchorage to growing biofilm inducing cell to cell contact (Jan et al. 2017), thus supporting action of adhesins. The high amounts of toxins, proteins, and virulence factors present in OMVs play a crucial role in the maintenance of communication, resource sharing between the bacterial cells and for host-pathogen interaction. Bacterial membrane vesicles are nanoparticles produced by both Gram-negative and Gram-positive bacteria. The adhesion in Gramnegative bacteria is accomplished by OMVs with the help of lipopolysaccharides (LPS).

The localization of chromosomal DNA in EVs from various Gram-negative pathogenic bacteria (Pseudomonas aeruginosa, Porphyromonas gingivalis, Salmonella Typhimurium) is mostly surface-associated (or extraluminal), which are involved in imparting virulence, stress response, antibiotic resistance, and metabolism (Chronopoulos and Kalluri 2020).

Bitto et al. (2017) had reported about source and putative function of impregnated DNA of OMVs of Pseudomonas aeruginosa, which is a notorious opportunistic Gram-negative multi-drug-resistant bacterium. It was described that the DNA present inside the OMVs are chromosomal in origin. The bacteria keep the extra amount of DNA in the cavity OMVs and extrude during log phase of its growth cycle (MacDonalda and Kuehn 
Table 1 Role of exosomes in pathogenic infections

\begin{tabular}{|c|c|c|c|c|c|}
\hline Microorganism & Strain & Host & Description & Role in infection & References \\
\hline \multirow[t]{15}{*}{ Bacteria } & Toxoplasma gondii & Macrophages & & $\begin{array}{l}\text { Activation of JNK path- } \\
\text { way and TH1 immune } \\
\text { responses }\end{array}$ & Li et al. (2018) \\
\hline & Klebsiella pneumoniae & $\begin{array}{l}\text { Cells of the epithelial } \\
\text { tissue }\end{array}$ & $\begin{array}{l}\text { Comprise of excess } \\
\text { amount the proteins } \\
\text { that originate from inner, } \\
\text { outer membrane, and } \\
\text { the periplasmic space }\end{array}$ & $\begin{array}{l}\text { Develops pro-inflam- } \\
\text { matory response within } \\
\text { the host }\end{array}$ & Lee et al. (2012) \\
\hline & $\begin{array}{l}\text { Mycobacterium tuber- } \\
\text { culosis }\end{array}$ & $\begin{array}{l}\text { Plasma and mac- } \\
\text { rophages }\end{array}$ & $\begin{array}{l}\text { It comprises of myco- } \\
\text { bacterial lipids and pro- } \\
\text { teins that are antigenic } \\
\text { in nature }\end{array}$ & $\begin{array}{l}\text { Develops pro-inflam- } \\
\text { matory response within } \\
\text { the host }\end{array}$ & Giri and Schorey (2008) \\
\hline & Mycobacterium avium & Macrophages & & $\begin{array}{l}\text { Develops pro-inflam- } \\
\text { matory response within } \\
\text { the host }\end{array}$ & Vázquez et al. (2012) \\
\hline & $\begin{array}{l}\text { Mycobacterium } \\
\text { bovis }\end{array}$ & Macrophages & $\begin{array}{l}\text { It comprises of myco- } \\
\text { bacterial lipids and pro- } \\
\text { teins that are antigenic } \\
\text { in nature }\end{array}$ & $\begin{array}{l}\text { Develops pro-inflam- } \\
\text { matory response within } \\
\text { the host }\end{array}$ & Giri and Schorey (2008) \\
\hline & Bacillus anthracis & $\begin{array}{l}\text { Cells of the epithelium } \\
\text { and the cells of the } \\
\text { retina }\end{array}$ & - & $\begin{array}{l}\text { Causes the lethal factor } \\
\text { to be transferred from } \\
\text { infected to uninfected } \\
\text { cells }\end{array}$ & $\begin{array}{l}\text { Bhatnagar and Schorey } \\
(2007)\end{array}$ \\
\hline & Chlamydia trachomatis & Fibroblast & $\begin{array}{l}\text { Comprise of bacterial } \\
\text { antigens like LPS and } \\
\text { MOMP }\end{array}$ & $\begin{array}{l}\text { They show cytotoxic } \\
\text { effect to the modulatory } \\
\text { proteins of human like } \\
\text { CT166, Pgp3, and CT159 }\end{array}$ & Frohlich et al. (2012) \\
\hline & Chlamydia pneumoniae & ECV304 cells & $\begin{array}{l}\text { TF m-RNA snd TF- } \\
\text { proteins }\end{array}$ & $\begin{array}{l}\text { Develops inflammatory } \\
\text { response resulting in the } \\
\text { development of vascular } \\
\text { disease }\end{array}$ & Ettelaie et al. (2007) \\
\hline & Salmonella typhimurium & Macrophages & Comprise of lipoprotein & $\begin{array}{l}\text { It causes proinflamma- } \\
\text { tory response }\end{array}$ & Bhatnagar et al. (2007) \\
\hline & Helicobacter pyroli & & Peptidoglycan & $\begin{array}{l}\text { In vivo and in vitro pro- } \\
\text { motion of inflammation }\end{array}$ & Kaparakis et al. (2010) \\
\hline & Moraxella catarrhalis & & $\begin{array}{l}\text { DNA and Moraxella lg-D } \\
\text { binding proteins }\end{array}$ & $\begin{array}{l}\text { Vesicle internalization } \\
\text { and B-cell receptor bind- } \\
\text { ing with the help of B } \\
\text { cell receptor }\end{array}$ & $\begin{array}{l}\text { Perez Vidakovics et al. } \\
(2010)\end{array}$ \\
\hline & Pseudomonas aeruginosa & & $\begin{array}{l}\text { t-RNA fragment and Cif } \\
\text { protein }\end{array}$ & $\begin{array}{l}\text { It causes reduction in } \\
\text { the clearance of patho- } \\
\text { gen and reduction in } \\
\text { antigen }\end{array}$ & Bomberger et al. (2014) \\
\hline & Neisseria gonorrhoeae & & Porin protein PorB & $\begin{array}{l}\text { It brings about apopto- } \\
\text { sis of macrophages by } \\
\text { activating the caspases } \\
\text { within the mitochondria }\end{array}$ & Deo et al. (2018) \\
\hline & Trypanosoma cruzi & & t-RNA halves & $\begin{array}{l}\text { Enhances the expression } \\
\mathrm{cxcl} 2 \text { and il- } 6 \text { within the } \\
\text { Hela cells }\end{array}$ & Garcia-Silva et al. (2014) \\
\hline & Plasmodium yoelii & Plasma and reticulocytes & & $\begin{array}{l}\text { It changes the tropism } \\
\text { of cells, modulation of } \\
\text { immune response and } \\
\text { reticulocytocis }\end{array}$ & Martin-Jaular et al. (2011) \\
\hline
\end{tabular}

2013). Further, it was reported that OMVs produced by Pseudomonas aeruginosa possess the ability to bring about transfer of DNA into the eukaryotic cells (Bitto et al. 2017). In addition, The DNA that is associated with the surface of the OMVs help in the development of biofilm and protection to the sessile microcolonies that are 
present within the biofilm (Figs. 1, 2). The OMVs from Ps. aeruginosa also possess greater amount of negatively charged B-bands, O-antigen heteropolymer (Rocchetta et al. 1999) of the LPS in comparison to neutral A-band

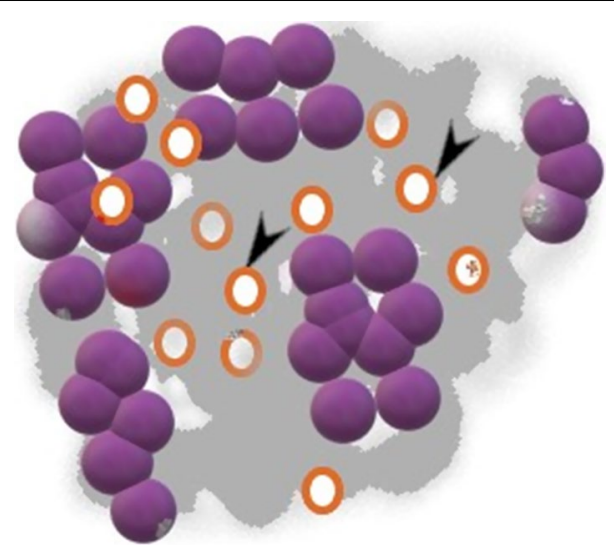

Fig. 1 An artwork depicting the role of membrane vesicles (Orange spheres, indicated by arrows) interlinking the microcolonies of biofilm producing Gram-positive typical Staphylococci
(Kadurugamuwa and Beveridge 1995). The possible reason behind this phenomenon is to accommodate the heteropolymer, diverse serotype O-Antigen, as outer membrane components.

Hence, it is inferred that DNA internal to OMVs may promote sharing of antibiotic resistance and virulence genes between bacteria through horizontal gene transfer, whereas DNA on the external surfaces of OMVs appears to be important for biofilm formation and protection of the biofilm (Liao et al. 2014).

It has been observed that the microvesicles (MVs) of Gram-positives play an important role in the maintenance of the intracellular matrix that is associated with the biofilm (Coelho and Casadevall 2019). The components that are associated with MVs help in bringing about the adhesive interactions taking place between the sessile microcolonies existing within the biofilm thereby maintaining its stability. It also helps in providing nutrient supply to the embedded cells within the matrix of biofilm and act as important factor in the development of antimicrobial resistance against various types of disinfectants (Toyofuku et al. 2012).

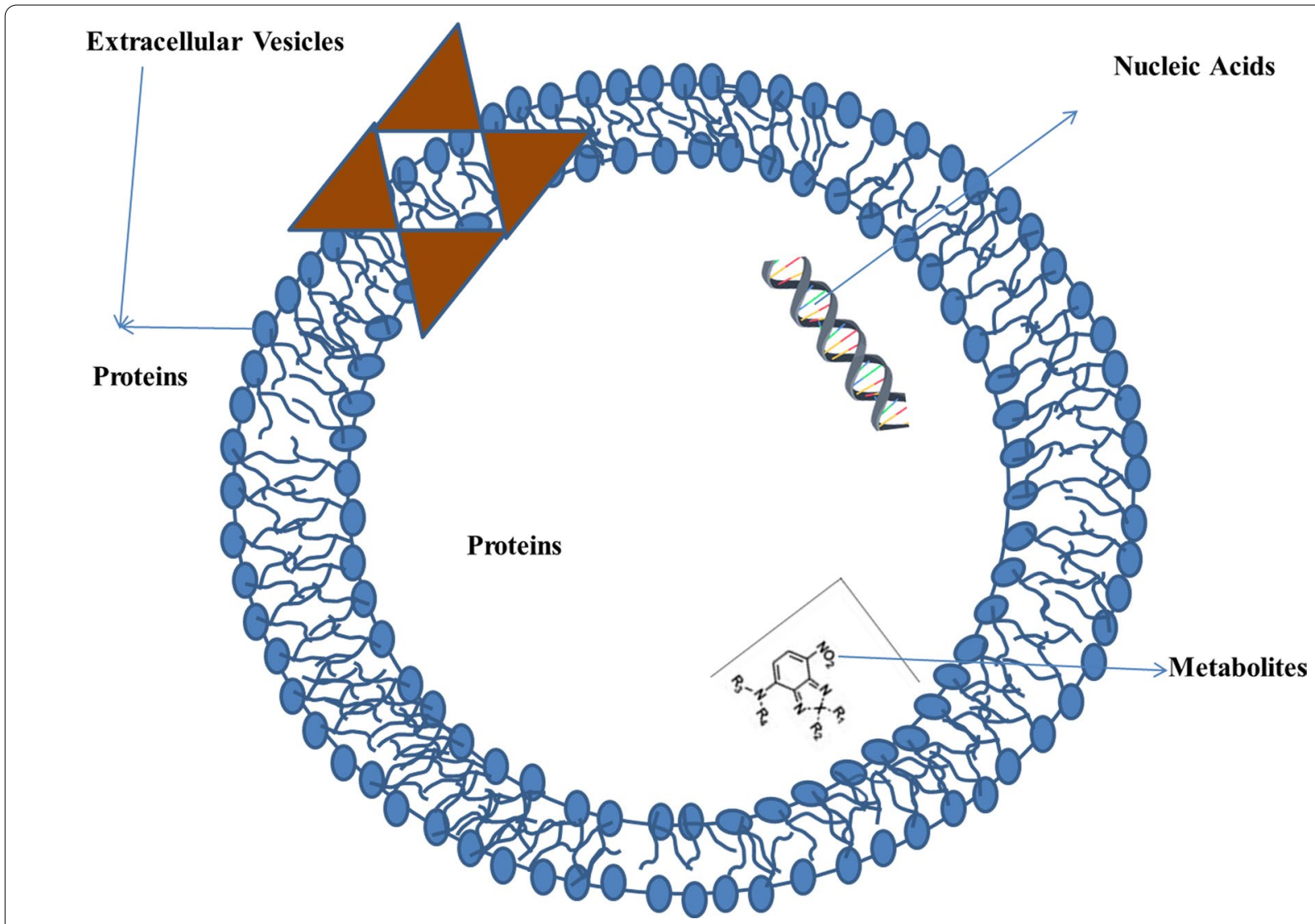

Fig. 2 Schematic representation of vesicles 


\section{Host-pathogen interaction of exosomes}

The bacteria deploy exosomes (Membrane vesicles) in response to immunological reactions, induced by the host immunological response. The MVs vary in accordance with their origin along with their function and composition. According to present understanding, the MVs have three primary functions, in the events of hostpathogen interaction. The functions are (a) The MVs act as mediators to transport the proteins, lipids, enzymes, drug-resistant genes, lytic enzymes, inducers for genes to carry out apoptic (programmed) cell death; (b) playing active role in 'escape mechanism' and (c) amplification of programmed cell death. Hence, the MVs are designated as 'structural and functional bridges between the invading pathogen and host.

MVs that usually bulge out of the plasma membrane causing explosive lysis of the cell that result in the degradation of bacterial cell walls. The phage-associated endolysins also possess the ability to bring about degradation of the peptidoglycans that are associated with Gram-positive bacterial cells and results in the development of cytoplasmic membrane vesicles (Coelho and Casadevall 2019) (Fig. 3).
The antigenic determinants of bacteria are processed by macrophages, dendritic cells and the antigen is presented, the CD4 and CD8 ligands are associated and the complex is called antigen-presenting cell (APC). In response to $\mathrm{APC}$, the cytokinins, interleukins are secreted and the inflammatory reaction is established. To counteract the immunological response conferred by the host, bacteria expel the exosomes in the form of intraluminal vesicles (Hurley 2010), which diffuse into the plasma membrane of host cell (Shorey et al. 2015). The candidate bacteria express its downstream genes for the exosome activation and endocytosis into host plasma membrane (Woodman and Futter 2008).

These membrane vesicles (MVs) partake in the transfer of various intercellular factors that result in the development of resistance against various types of disinfectants and antibiotics (Rodrigues et al. 2008). It was also reported that MVs carry various types of virulence factors and endotoxins that are produced by Gram-positive and Gram-negative bacterial species (Coelho and Casadevall 2019), as well.

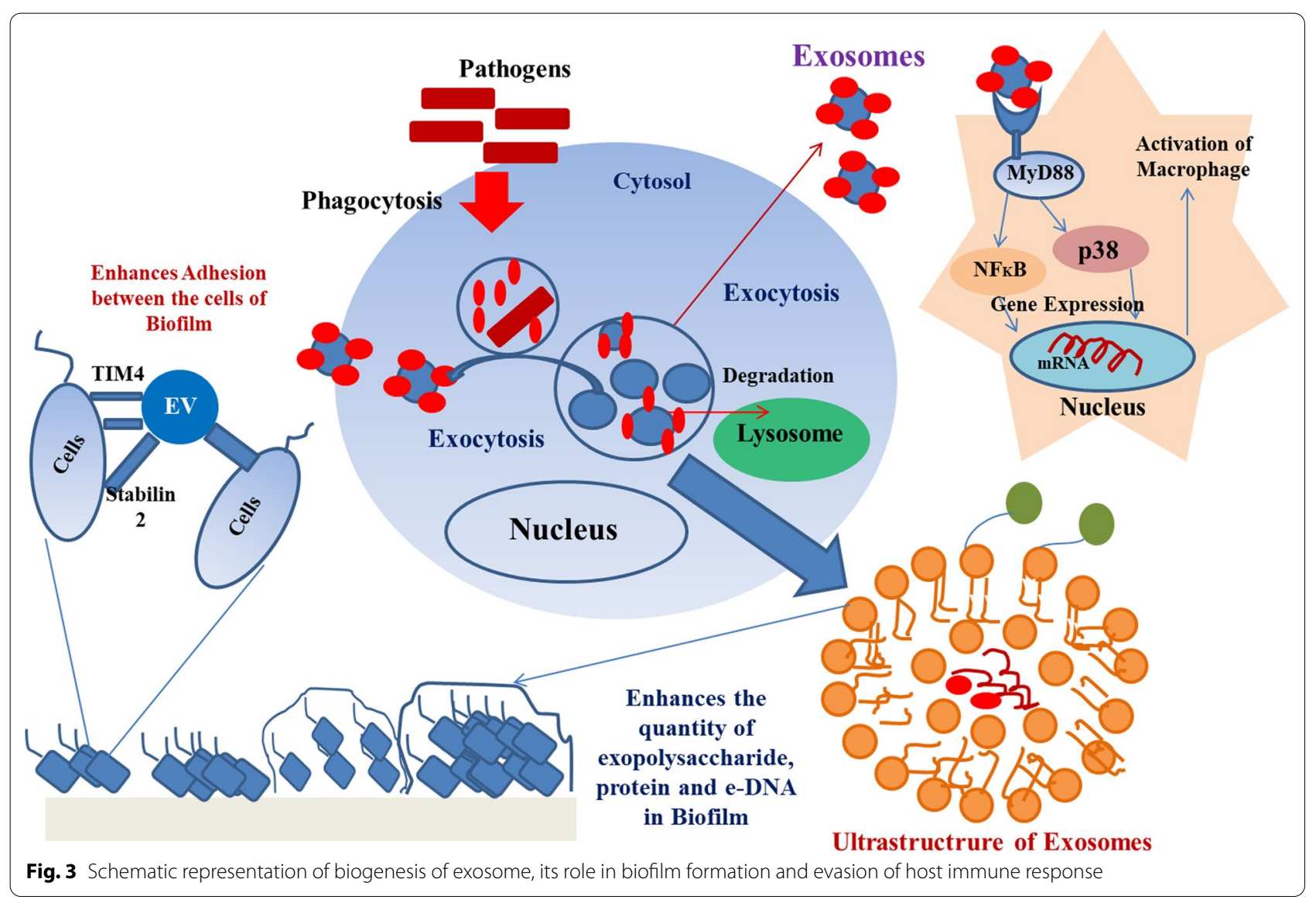




\section{Evasion of immune reaction by (Outer Membrane Vesicles) OMVs}

As mentioned earlier, outer-membrane vesicles (OMVs) are spherical buds of the outer membrane filled with periplasmic content (Fig. 4) and are commonly produced by Gram-negative bacteria (Schwechheimer and Kuehn 2015).

The OMVs result in the development of pathogenesis within the eukaryotic cells by the delivery of various types of virulence factors and toxins and also bring about change in the homeostasis of the immune system (Celluzzi and Masotti 2016). It has been observed that OMVs produced by Bacteroides thetaiotaomicron within the mucosal walls of gut are responsible for the inflammation of the intestine (Pathirana and Kaparakis-Liaskos 2016). Besides they can bring about caveolin-mediated endocytosis, non-clathrin-mediated endocytosis, clathrin-mediated endocytosis and macro-pinocytosis ( $\mathrm{O}^{\prime}$ Donoghue and Krachler 2016). OMVs show resistance to various types of degradative enabling them for easy evasion to the host immune system (Bonnington and Kuehn 2014). It has been observed that OMVs produced by Moraxella catarrhalis to guide the cell in evading the host immune system (Perez Vidakovics et al. 2010). This also helps in colonization of bacterial cells by killing or promoting the growth of other bacterial cells (Hickey et al. 2015).

The exposure of the bacterial cells to environmental stresses like antibiotics and environmental contaminants results in the evolution of OMVs and generation of efflux of multidrug pumps thereby preventing the penetration of the antibiotics up to the sessile microcolonies (Manning and Kuehn 2011). The OMVs also possess the ability to enhance the expression of the surface-associated receptors and activate $A B C$ transporter thereby enhances the survival of bacteria. The enhancement of stress response of the bacterial cells takes place by the production of various types of unfolded and misfolded proteins to OMVs (Baumgarten et al. 2012). They are also responsible for the deliverance of the components associated with extracellular matrix and growth factors (Klimentová

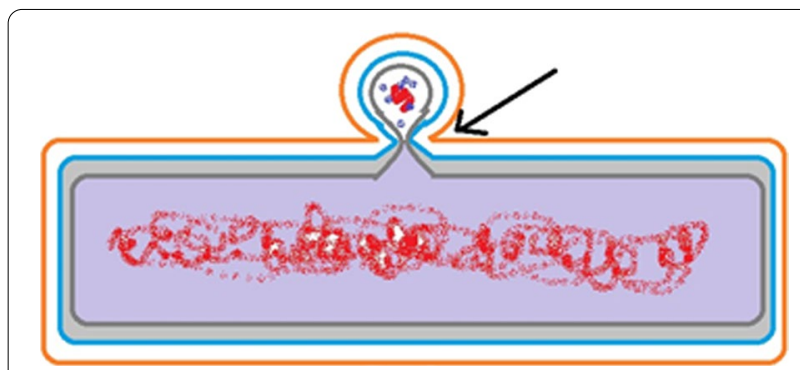

Fig. 4 The blebbing of OMV from atypical Gram-negative bacteria (arrow indicates the point of blebbing) and Stulík 2015). The exopolysaccharides that are released by OMVs enhance the aggregation of the cells within the biofilm thereby shifts from the planktonic to sessile forms causing enhanced biofilm formation (Klimentová and Stulík 2015). The OMVs also possess the ability to protect the bacterial cells from the action of antimicrobial peptides and act as a carriage for determinants of resistance.

\section{Role of extracellular vesicles (EVs) on polymicrobial biofilm}

Exosomes are the biologically produced EVs that are produced by various types of the cells. The EVs are responsible for the maintenance of intercellular signaling by transference of RNA, DNA, and various types of proteins. Typically, Gram-positive bacteria readily produce extracellular vesicles (EVs). Lee et al. (2013) had mentioned that Staphylococcus aureus would unshackle BlaZ, a $\beta$-lactamase protein, using EVs as carrier. Hansol Im et al. (2017) had inferred that $S$. aureus had utilized EVs for restricting the biofilm growth by other bacteria, namely Acinetobacter baumannii, thus annotating a function to EVs as 'surface binding antagonistics.' However, it was observed that there is a coordination of different bacterial species to form a biofilm on a particular surface, which is called as a 'Polymicrobial biofilm' (Willems et al. 2016). The dental caries, GI tract, etc., are co-infected by either different species of bacteria/bacteria-virus/bacteria-fungal/viral-fungal strains. In this case, nutrition circularization is made by EVs. It is now reported that EVs secreted during viral infection promote secondary bacterial growth and biofilm formation (as in Pseudomonas aeruginosa after the viral infection) by vesicular delivery of nutrient and other factors and thereby proved to offer evidence of trans-kingdom communication in the setting of polymicrobial biofilm in host body (Hendricks et al. 2021).

\section{Conclusion and future prospects}

It is clear that exosomes play a crucial role in the biogenesis of multispecies even trans-kingdom biofilm matrix which encourages the establishment of co-infection and pathogenic intervention by opportunistic pathogens. As the emergence of multi-drug resistance in clinical setup is acute evidence, exosomes should be considered as alternative drug targets. Efforts should be made, in targeting the EVs produced and selective destruction or blockage of their release may open an avenue for reducing the dreadful pathogenic effect of biofilm borne microbes toward their host.

\section{Acknowledgements}

Not applicable. 


\section{Authors' contributions}

$\mathrm{DL}, \mathrm{MN}, \mathrm{AD}$, and TS. contributed to conceptualization; SP, SG, HAE, SP, ZAK, and RR contributed to methodology; $\mathrm{DL}, \mathrm{MN}, \mathrm{AD}$, and TS contributed to data collection; DL, MN, AD and TS, SP, SG, HAE, SP, ZAK, and RR contributed to writing —original draft preparation; DL, MN, AD and TS, SP, SG, HAE, SP, ZAK and RR contributed to writing - review and editing. All authors have read and agreed to the published version of the manuscript.

\section{Funding}

Not Applicable.

\section{Availability of data and materials}

All data generated or analyzed during this study are included in this published article.

\section{Declarations}

Ethics approval and consent to participate

Not Applicable.

\section{Consent for publication}

All authors have consent to publish the paper.

\section{Competing interests}

The authors declare that they have no competing interests.

\section{Author details}

${ }^{1}$ Department of Biotechnology, University of Engineering and Management, Kolkata, India. ${ }^{2}$ Department of Biotechnology, Maulana Abul Kalam Azad University of Technology, West Bengal, Haringhata, India. ${ }^{3}$ Department of Food Technology and Biochemical Engineering, Faculty of Engineering and Technology, Jadavpur University, Kolkata, India. ${ }^{4}$ Malda Polytechnic, West Bengal State Council of Technical Education, Government of West Bengal, Malda, India. ${ }^{5}$ Department of Biotechnology and Bioinformatics, Sambalpur University, Sambalpur, Odisha, India. ${ }^{6}$ Department of Microbiology, School of Science, R.K. University, Rajkot, Gujarat, India. ${ }^{7}$ Forensic Science Programme, School of Health Sciences, Universiti Sains Malaysia, Kota Baharu, Kelantan, Malaysia. ${ }^{8}$ Research Division, Association for Biodiversity Conservation and Research $(\mathrm{ABC})$, Balasore, Odisha, India. ${ }^{9}$ Centre of Excellence, Khallikote University, Berhampur, India. ${ }^{10}$ Faculty of Agro Based Industry, Universiti Malaysia Kelantan, Jeli, Malaysia.

Received: 15 July 2021 Accepted: 7 October 2021

Published online: 11 November 2021

\section{References}

Abels ER, Breakefield XO. Introduction to extracellular vesicles: biogenesis, RNA Cargo selection, content, release, and uptake. Cell Mol Neurobiol. 2016:36:301-12. https://doi.org/10.1007/s10571-016-0366-z.

Baumgarten T, Sperling S, Seifert J, von Bergen M, Steiniger F, Wick LY, et al. Membrane vesicle formation as a multiple-stress response mechanism enhances Pseudomonas putida DOT-T1E cell surface hydrophobicity and biofilm formation. Appl Environ Microbiol. 2012;78:6217-24. https://doi. org/10.1128/AEM.01525-12.

Bhatnagar S, Schorey JS. Exosomes released from infected macrophages contain Mycobacterium avium glycopeptidolipids and are proinflammatory. J Biol Chem. 2007;282:25779-89. https://doi.org/10.1074/jbc.M702277200.

Bhatnagar S, Shinagawa K, Castellino FJ, Schorey JS. Exosomes released from macrophages infected with intracellular pathogens stimulate a proinflammatory response in vitro and in vivo. Blood. 2007;110:3234-44. https://doi.org/10.1182/blood-2007-03-079152.

Bitto NJ, Chapman R, Pidot S, Costin A, Lo C, Choi J, et al. Bacterial membrane vesicles transport their DNA cargo into host cells. Sci Rep. 2017;7:7072. https://doi.org/10.1038/s41598-017-07288-4

Bomberger JM, Ely KH, Bangia N, Ye S, Green KA, Green WR, et al. Pseudomonas aeruginosa Cif protein enhances the ubiquitination and proteasomal degradation of the transporter associated with antigen processing (TAP) and reduces major histocompatibility complex (MHC) class I antigen presentation. J Biol Chem. 2014;289:152-62. https://doi.org/10.1074/jbc. M113.459271.

Bonnington KE, Kuehn MJ. Protein selection and export via outer membrane vesicles. Biochim Biophys Acta. 2014;1843:1612-9. https://doi.org/10. 1016/j.bbamcr.2013.12.011.

Caruana JC, Walper SA. Bacterial membrane vesicles as mediators of microbemicrobe and microbe-host community interactions. Front Microbiol. 2020;11:432. https://doi.org/10.3389/fmicb.2020.00432.

Celluzzi A, Masotti A. How our other genome controls our epi-genome. Trends Microbiol. 2016;24:777-87. https://doi.org/10.1016/j.tim.2016.05.005.

Chronopoulos A, Kalluri R. Emerging role of bacterial extracellular vesicles in cancer. Oncogene. 2020;39:6951-60. https://doi.org/10.1038/ s41388-020-01509-3.

Coelho C, Casadevall A. Answers to naysayers regarding microbial extracellular vesicles. Biochem Soc Trans. 2019;47:1005-12. https://doi.org/10.1042/ BST20180252.

Cooke AC, Nello AV, Ernst RK, Schertzer JW. Analysis of Pseudomonas aeruginosa biofilm membrane vesicles supports multiple mechanisms of biogenesis. PLoS ONE. 2019;14:e0212275. https://doi.org/10.1371/journ al.pone.0212275.

Deo P, Chow SH, Hay ID, Kleifeld O, Costin A, Elgass KD, et al. Outer membrane vesicles from Neisseria gonorrhoeae target PorB to mitochondria and induce apoptosis. PLoS Pathog. 2018;14:e1006945. https://doi.org/10. 1371/journal.ppat.1006945.

Ettelaie C, Collier MEW, James NJ, Li C. Induction of tissue factor expression and release as microparticles in ECV304 cell line by Chlamydia pneumoniae infection. Atherosclerosis. 2007;190:343-51. https://doi.org/10. 1016/j.atherosclerosis.2006.04.005.

Frohlich K, Hua Z, Wang J, Shen L. Isolation of Chlamydia trachomatis and membrane vesicles derived from host and bacteria. J Microbiol Methods. 2012:91:222-30. https://doi.org/10.1016/j.mimet.2012.08.012.

Garcia-Silva MR, Cabrera-Cabrera F, Cura das Neves RF, Souto-Padrón T, de Souza W, Cayota A. Gene expression changes induced by Trypanosoma cruzi Shed microvesicles in mammalian host cells: relevance of tRNAderived halves. Biomed Res Int. 2014. https://doi.org/10.1155/2014/ 305239.

Giri PK, Schorey JS. Exosomes derived from M. Bovis BCG infected macrophages activate antigen-specific CD4+ and CD8+ T cells in vitro and in vivo. PLOS ONE. 2008;3:e2461. https://doi.org/10.1371/journal.pone. 0002461.

Henderson IR, Navarro-Garcia F, Desvaux M, Fernandez RC, Ala'Aldeen D. Type $\checkmark$ protein secretion pathway: the autotransporter story. Microbiol Mol Biol Rev. 2004;68:692-744. https://doi.org/10.1128/MMBR.68.4.692-744.2004.

Hickey CA, Kuhn KA, Donermeyer DL, Porter NT, Jin C, Cameron EA, et al. Colitogenic bacteroides thetaiotaomicron antigens access host immune cells in a sulfatase-dependent manner via outer membrane vesicles. Cell Host Microbe. 2015;17:672-80. https://doi.org/10.1016/j.chom.2015.04.002.

Hurley JH. The ESCRT complexes. Crit Rev Biochem Mol Biol. 2010;45:463-87. https://doi.org/10.3109/10409238.2010.502516.

Hendricks MR, Lane S, Melvin JA, Ouyang Y, Stolz DB, Williams JV, Sadovsky Y, Bomberger JM. Extracellular vesicles promote transkingdom nutrient transfer during viral-bacterial co-infection. Cell Rep. 2021;34(4):108672.

Im H, Lee S, Soper SA, Mitchell RJ. Staphylococcus aureus extracellular vesicles (EVs): surface-binding antagonists of biofilm formation. Mol BioSyst. 2017;13(12):2704-14. https://doi.org/10.1039/c7mb00365j.

Jan AT. Outer membrane vesicles (OMVs) of gram-negative bacteria: a perspective update. Front Microbiol. 2017:8:1053. https://doi.org/10.3389/ fmicb.2017.01053.

Kadurugamuwa JL, Beveridge TJ. Virulence factors are released from Pseudomonas aeruginosa in association with membrane vesicles during normal growth and exposure to gentamicin: a novel mechanism of enzyme secretion. J Bacteriol. 1995;177:3998-4008. https://doi.org/10.1128/jb.177. 14.3998-4008.1995.

Kalluri R, LeBleu VS. The biology, function, and biomedical applications of exosomes. Science. 2020;367:eaau6977. https://doi.org/10.1126/science. aau6977.

Kaparakis M, Turnbull L, Carneiro L, Firth S, Coleman HA, Parkington HC, et al. Bacterial membrane vesicles deliver peptidoglycan to NOD1 in epithelial cells. Cell Microbiol. 2010;12:372-85. https://doi.org/10.1111/j.1462-5822. 2009.01404.x. 
Klimentová J, Stulík J. Methods of isolation and purification of outer membrane vesicles from gram-negative bacteria. Microbiol Res. 2015;170:1-9. https://doi.org/10.1016/j.micres.2014.09.006.

Lee E-Y, Choi D-Y, Kim D-K, Kim J-W, Park JO, Kim S, et al. Gram-positive bacteria produce membrane vesicles: proteomics-based characterization of Staphylococcus aureus-derived membrane vesicles. Proteomics. 2009:9:5425-36. https://doi.org/10.1002/pmic.200900338.

Lee JC, Lee EJ, Lee JH, Jun SH, Choi CW, Kim SI, et al. Klebsiella pneumoniae secretes outer membrane vesicles that induce the innate immune response. FEMS Microbiol Lett. 2012;331:17-24. https://doi.org/10.1111/j. 1574-6968.2012.02549.x.

Lee J, Lee EY, Kim SH, Kim DK, Park KS, Kim KP, et al. Staphylococcus aureus extracellular vesicles carry biologically active $\beta$-lactamase. Antimicrob Agents Chemother. 2013;57(6):2589-95. https://doi.org/10.1128/AAC. 00522-12

Li Y, Xiu F, Mou Z, Xue Z, Du H, Zhou C, et al. Exosomes derived from Toxoplasma gondii stimulate an inflammatory response through JNK signaling pathway. Nanomedicine (Lond). 2018;13:1157-68. https://doi.org/10. 2217/nnm-2018-0035.

Liao S, Klein MI, Heim KP, Fan Y, Bitoun JP, Ahn S-J, et al. Streptococcus mutans extracellular DNA is upregulated during growth in biofilms, actively released via membrane vesicles, and influenced by components of the protein secretion machinery. J Bacteriol. 2014;196:2355-66. https://doi. org/10.1128/JB.01493-14.

MacDonald IA, Kuehn MJ. Stress-induced outer membrane vesicle production by Pseudomonas aeruginosa. J Bacteriol. 2013;195(13):2971-81. https:// doi.org/10.1128/JB.02267-12.

Manning AJ, Kuehn MJ. Contribution of bacterial outer membrane vesicles to innate bacterial defense. BMC Microbiol. 2011;11:258. https://doi.org/10. 1186/1471-2180-11-258.

Marsollier L, Brodin P, Jackson M, Korduláková J, Tafelmeyer P, Carbonnelle E, et al. Impact of Mycobacterium ulcerans biofilm on transmissibility to ecological niches and buruli ulcer pathogenesis. PLoS Pathog. 2007;3:e62. https://doi.org/10.1371/journal.ppat.0030062.

Martin-Jaular L, Nakayasu ES, Ferrer M, Almeida IC, del Portillo HA. Exosomes from Plasmodium yoelii-infected reticulocytes protect mice from lethal infections. PLoS ONE. 2011;6:e26588. https://doi.org/10.1371/journal. pone.0026588.

O'Donoghue EJ, Krachler AM. Mechanisms of outer membrane vesicle entry into host cells. Cell Microbiol. 2016;18:1508-17. https://doi.org/10.1111/ cmi.12655.

Pathirana RD, Kaparakis-Liaskos M. Bacterial membrane vesicles: biogenesis, immune regulation and pathogenesis. Cell Microbiol. 2016;18:1518-24. https://doi.org/10.1111/cmi.12658.

Perez Vidakovics MLA, Jendholm J, Mörgelin M, Månsson A, Larsson C, Cardell L-O, et al. B cell activation by outer membrane vesicles-a novel virulence mechanism. PLoS Pathog. 2010;6:e1000724. https://doi.org/10. 1371/journal.ppat.1000724.

Rocchetta HL, Burrows LL, Lam JS. Genetics of O-antigen biosynthesis in Pseudomonas aeruginosa. Microbiol Mol Biol Rev. 1999;63(3):523-53.

Rodrigues ML, Nakayasu ES, Oliveira DL, Nimrichter L, Nosanchuk JD, Almeida IC, et al. Extracellular vesicles produced by Cryptococcus neoformans contain protein components associated with virulence. Eukaryot Cell. 2008;7:58-67. https://doi.org/10.1128/EC.00370-07.

Samanta S, Rajasingh S, Drosos N, Zhou Z, Dawn B, Rajasingh J. Exosomes: new molecular targets of diseases. Acta Pharmacol Sin. 2018;39(4):501-13. https://doi.org/10.1038/aps.2017.162.

Schwechheimer C, Kuehn MJ. Outer-membrane vesicles from Gram-negative bacteria: biogenesis and functions. Nat Rev Microbiol. 2015;13(10):60519. https://doi.org/10.1038/nrmicro3525.

Schorey JS, Cheng Y, Singh PP, Smith VL. Exosomes and other extracellular vesicles in host-pathogen interactions. EMBO Rep. 2015;16(1):24-43. https:// doi.org/10.15252/embr.201439363.

Seike S, Kobayashi H, Ueda M, Takahashi E, Okamoto K, Yamanaka H. Outer membrane vesicles released from Aeromonas strains are involved in the biofilm formation. Front Microbiol. 2020. https://doi.org/10.3389/fmicb. 2020.613650

Toyofuku M, Roschitzki B, Riedel K, Eberl L. Identification of proteins associated with the Pseudomonas aeruginosa biofilm extracellular matrix. J Proteome Res. 2012;11:4906-15. https://doi.org/10.1021/pr300395j.

Vázquez N, Rekka S, Gliozzi M, Feng CG, Amarnath S, Orenstein JM, Wahl SM. Modulation of innate host factors by Mycobacterium avium complex in human macrophages includes interleukin 17. J Infect Dis. 2012;206(8):1206-17. https://doi.org/10.1093/infdis/jis492.

Wang W, Chanda W, Zhong M. The relationship between biofilm and outer membrane vesicles: a novel therapy overview. FEMS Microbiol Lett. 2015. https://doi.org/10.1093/femsle/fnv117.

Willems HM, Xu Z, Peters BM. Polymicrobial biofilm studies: from basic science to biofilm control. Curr Oral Health Rep. 2016;3(1):36-44. https://doi.org/ 10.1007/s40496-016-0078-y.

Woodman PG, Futter CE. Multivesicular bodies: co-ordinated progression to maturity. Curr Opin Cell Biol. 2008;20:408-14. https://doi.org/10.1016/j. ceb.2008.04.001.

Zaborowski MP, Balaj L, Breakefield XO, Lai CP. Extracellular vesicles: composition, biological relevance, and methods of study. Bioscience. 2015;65(8):783-97.

\section{Publisher's Note}

Springer Nature remains neutral with regard to jurisdictional claims in published maps and institutional affiliations.

\section{Submit your manuscript to a SpringerOpen ${ }^{\circ}$ journal and benefit from:}

- Convenient online submission

- Rigorous peer review

- Open access: articles freely available online

- High visibility within the field

- Retaining the copyright to your article

Submit your next manuscript at springeropen.com 